\title{
DAMPAK TERMINAL MANGKANG KOTA SEMARANG DAN PERMASALAHAN DI KAWASAN SEKITARNYA Studi Kasus : Terminal Mangkang Semarang
}

\author{
Dyah Andriyanti' ${ }^{1}$ Rachmat Mudiyono ${ }^{2}$ \\ Program Studi Perencanaan Wilayah dan Kota Universitas Islam Sultan Agung Semarang ${ }^{1), 2)}$
}

\section{ABSTRACT}

This study aims to determine the effect of the presence of terminal Mangkang Semarang to the problems in the surrounding area. In addition to the above-mentioned objectives of this research has the goal to identify Semarang city transportation management, transportation terminals Mangkang analysis, sera footprint analysis to find out the problems that arise, land use, and the use of function space. To achieve the goals and objectives of the research, the method of analysis used is descriptive qualitative analysis.

Based on the analysis showed that the terminal performance is less effective and efficient impact on the problems in the surrounding area that the transportation problems in front Mangkang terminal form of congestion caused by transport stops outside the terminal, use less maksmial kiosks that appear hawkers, and environmental problems in the area of the terminal. From the analysis carried out resulted in a recommendation that is used as an alternative in solving problems encountered in general in the terminal region Mangang related to transportation management, transportation terminals, and terminal area footprint.

Keywords : Transportation, Terminal, Regional development.

\begin{abstract}
ABSTRAK
Penelitian ini bertujuan untuk mengetahui dampak keberadaan terminal Mangkang Kota Semarang terhadap permasalahan di kawasan sekitarnya. Selain tujuan tersebut diatas penelitian ini mempunyai sasaran untuk mengindentifikasi manajemen transportasi kota Semarang, analisis sarana transportasi Terminal Mangkang, sera analisis tapak untuk mengetahui permasalahan yang muncul, tata guna lahan, dan pemanfaatan fungsi ruang. Untuk mencapai tujuan dan sasaran penelitian, metode analisis yang digunakan adalah analisis deskriptif kualitatif.

Berdasarkan analisis didapatkan hasil bahwa Kinerja terminal yang kurang efektif dan efisien berdampak pada permasalahan di kawasan sekitarnya yaitu permasalahan pada transportasi yang berada didepan terminal Mangkang berupa kemacetan yang disebabkan oleh adanya pemberhentian angkutan di luar terminal, pemanfaatan kios yang kurang maksmial sehingga muncul pedagang kaki lima, dan permasalahan lingkungan di kawasan terminal. Dari analisis yang dilakukan menghasilkan rekomendasi yang digunakan sebagai alternatif dalam penyelesaian masalah yang ditemui secara umum di kawasan terminal Mangang yang berkaitan dengan manajemen transportasi, sarana transportasi terminal, maupun tapak kawasan terminal.
\end{abstract}

Kata Kunci : Transportasi, Terminal, Pengembangan kawasan 


\section{PENDAHULUAN}

\section{Latar Belakang}

Fasilitas prasarana dan sarana transportasi merupakan indikator kemajuan kesejahteraan masyarakat dalam suatu daerah. Perbaikan dalam prasarana dan sarana transportasi pada umumnya akan dapat meningkatkan mobilitas penduduk, meningkatnya kelancaran keluar masuk barang-barang dan perbaikan kualitas jasa-jasa pengangkutan. Sehingga dengan adanya fasilitas prasarana dan sarana transportasi di suatu daerah mampu meningkatkan kesejahteraan masyarakat dan menambah nilai positif bagi suatu daerah.

Terminal merupakan simpul dalam sistem jaringan transportasi jalan yang berfungsi pokok sebagai pelayanan umum yaitu tempat untuk naik turun penumpang atau bongkar muat barang, untuk pengendalian lalu lintas dan angkutan kendaraan umum, serta sebagai tempat pemberhentian intra dan antar moda transportasi. Sesuai dengan fungsi tersebut, maka penyenggaraan terminal berperan menunjang tersedianya jasa transportasi yang sesuai dengan tingkat kebutuhan lalu lintas dan pelayanan angkutan yang selamat, aman, cepat, tepat, teratur dan dengan biaya yang terjangkau masyarakat.

Kota Semarang merupakan salah satu kota terpadat dimana terdapat banyak aktivitas mapun kegiatan yang berpusat di Kota Semarang. Kota Semarang juga menjadi konektor antar kota di sekitar Kota Semarang, banyak wisatawan yang berkunjung maupun sekedar transit di Kota Semarang. Menurut Gretzel, et al., (2004) pelayanan transportasi merupakan salah satu sarana pendukung untuk memberikan nuansa nyaman bagi seorang wisatawan (Soebiyantoro, 2010). Semarang memiliki pelabuhan udara domestik (Bandara Ahmad Yani), pelabuhan laut yang besar (Pelabuhan Tanjung Mas), serta terminal bus. Dengan moda-moda transportasi tersebut, Semarang difungsikan sebagai kota transit. Hal ini merupakan potensi Kota Semarang untuk menjadi pintu jalur distribusi dan pusat pertumbuhan bagi wilayah-wilayah di sekitarnya. Untuk menggali potensi ini lebih jauh serta mengantisipasi kepadatan transportasi di tengah kota, maka adanya sarana dan prasarana transportasi berupa terminal yang terletak di tepi kota sangat mempengaruhi perkembangan transportasi, salah satu upayanya adalah dalam pengembangan Terminal Mangkang.

Terminal Kota Semarang yang terletak di Mangkang (Kecamatan Tugu) merupakan salah satu terminal tipe A di Kota Semarang yang melayani bus AKAP jurusan Jakarta Surabaya dan Trans Semarang Koridor 1. Terminal Mangkang dibangun sejak tahun 2002, 
dan sudah mengalami beberapa renovasi hingga tahun 2005. Terminal ini dibangun untuk mengurangi kepadatan lalu lintas bus-bus antar kota dari arah Barat ke Timur dan arah Selatan ke Barat. Namun pada kenyataannya masih banyak bus yang berhenti di luar terminal dan mengganggu arus lalu lintas di sepanjang jalan arteri primer. Bangunan terminal juga belum optimal pemanfaatannya karena cenderung sepi dan belum dimanfaatkan secara maksimal oleh penumpang. Selain itu, keberadaan terminal bayangan di sekitar Terminal Mangkang juga semakin menambah nilai negatif bagi Terminal Mangkang yang menyebabkan Terminal Mangkang sepi. Terminal bayangan merupakan tempat ilegal dengan oknum-oknum yang biasa melakukan pungutan. Keberadaan terminal muncul karena akses yang mudah serta jarak dengan kota yang tidak terlalu jauh. Hal ini berdampak negatif bagi terminal utama seperti Terminal Mangkang yang menjadi sepi. Menurut data pada tahun 2013, koridor I jurusan Terminal Mangkang-Penggaron pada Bulan Januari jumlah penumpang BRT sebanyak 160.451, pada Bulan February terjadi penurunan penumpang sebanyak 7,7\% menjadi 148.072 orang, pada Bulan Maret jumlah penumpang sebanyak 172.474 orang, pada Bulan April kembali mengalai penurunan menjadi 169.501 (Siahaan Daniel Adam's, dkk 2013).

Adanya Isu pembangunan Stasiun yang terkoneksi dengan terminal, menjawab permasalahan-permasalahan di atas. Terminal Mangkang diandalkan menjadi terminal yang terintegrasi dan memberikan kenyamanan serta keamanan bagi penggunan transportasi umum. Hal tersebut dapat berpengaruh pada perkembangan kawasan sekitarnya sehingga memerlukan penanganan dengan penerapan kebijakan. Kebijakan ini adalah sebagai langkah untuk mengoptimalkan fungsi Terminal Mangkang.

\section{METODOLOGI}

Metode pendekatan dalam penelitian ini adalah metode pendekatan deskriptif kualitatif positivistik. Dalam hal ini studi yang digunakan dalam analisis yaitu:

Manajemen transportasi yaitu analisis untuk mengetahui sistem transportasi.

\section{a. Lalu lintas harian rata-rata (LHR)}

LHR dihitung dari hasil survei trafic counting yang dilakukan di dua titik yang dibagi menjadi dua ruas jalan yaitu menuju Semarang dan menuju Kendal.

$$
\text { LHR }=\frac{\text { Jumlah Lalu Lint as Selama Pengamatan }}{\text { Lamanya Pengama } \tan }
$$


Jumlah lalu lintas umumnya ditetapkan dalam SMP (Satuan Mobil Penumpang).

\section{b. Tingkat Pelayanan Jalan (Level Of Service)}

Nilai tingkat pelayanan jalan diperoleh dari perbandingan volume lalu-lintas (V) dengan Kapasitas jalan (C), atau dapat ditulis ratio V/C. Semakin besar nilai V/C rasio maka tingkat pelayanan jalannya semakin buruk. Sebaliknya, jika semakin kecil nilai rasio V/C maka tingkat pelayanan jalannya semakin baik.

$$
\text { Los of service }=\frac{\text { Volume lalu lintas }}{\text { Kapasitas }} \text { atau }=\frac{\mathrm{V}(\mathrm{SMP} / \mathrm{Jam})}{\mathrm{C}(\mathrm{SMP} / \mathrm{Jam})}
$$

c. Proyeksi Lalu Lintas Harian Rata-Rata (LHR)

Untuk memperkirakan pertumbuhan lalu lintas pada tahun yang akan datang dapat dihitung dengan rumus :

$$
\begin{aligned}
& \text { LHRn }=\text { LHRo }(1+\mathrm{i})^{\mathrm{n}} \\
& \text { dimana }: \text { LHRn }=\text { LHR tahun ke-n } \\
& \qquad \begin{array}{l}
\text { LHRo }=\text { LHR awal tahun rencana : } \\
\text { I }=\text { Faktor pertumbuhan } \\
\text { n }=\text { Umur rencana }(\%) \text { Proyeksi hingga } 20 \text { tahun mendatang }(\mathrm{n}=20) .
\end{array}
\end{aligned}
$$

\section{HASIL DAN PEMBAHASAN}

\section{Kondisi Eksisting Terminal Mangkang Kota Semarang}

Terminal Mangkang berada di perbatasan dengan Kabupaten Kendal atau sebelah barat Kota Semarang. Keberadaan Terminal Mangkang merupakan terminal tipe A.

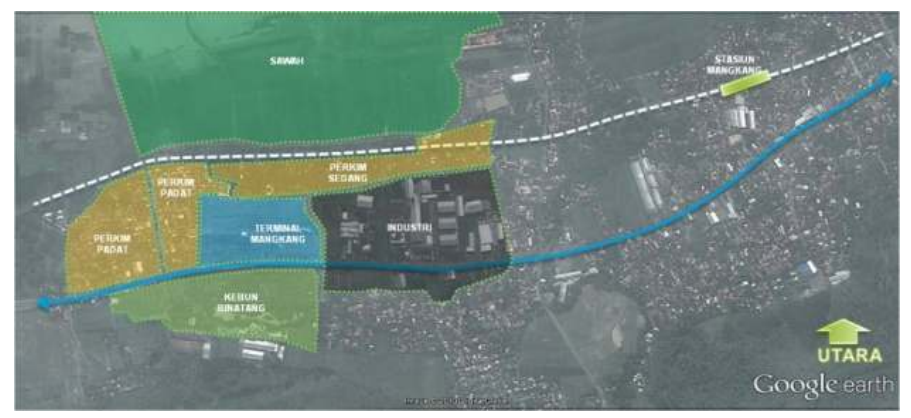

Gambar 1. Tata Guna Lahan Kawasan Terminal Mangkang (Sumber : Google Earth dan Modifikasi, 2015)

Terminal Mangkang yang sudah jadi saat ini merupakan emplasemen trayek busbus yang melayani pergerakan dalam kota. 


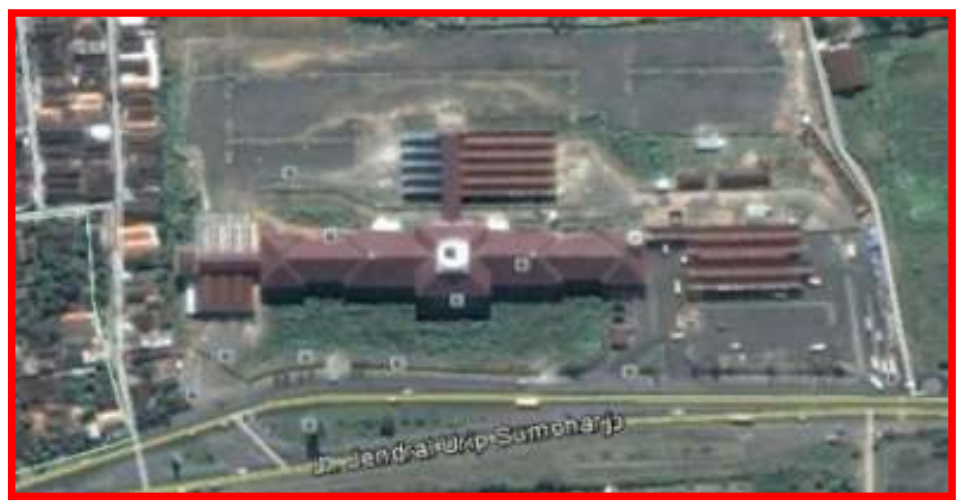

Gambar 2 Foto Udara Kawasan Terminal Mangkang

Sumber : Google Earth

\subsection{Analisis Dampak Keberadaan Terminal Mangkang Kota Semarang Terhadap \\ Permasalahan Di Kawasan Sekitarnya}

\section{Analisis Manjemen Transportasi}

\section{a. Lalu lintas harian rata-rata (LHR)}

Untuk ruas jalan menuju ke Semarang LHR tertinggi pada pagi hari yaitu sebesar $4648 \mathrm{SMP} / \mathrm{jam}$, kemudian pada sore hari yaitu sebesar $4145 \mathrm{SMP} / \mathrm{jam}$. Tingginya nilai LHR pada kedua waktu tersebut karena dipengaruhi oleh pergerakan pekerja (pada jam berangkat dan pulang kerja). Sedangkan LHR pada siang hari hanya sebesar 3868 $\mathrm{SMP} / \mathrm{jam}$.

Nilai LHR menuju ke Kendal pada pagi, siang dan sore hari menunjukkan perbedaan yang cukup signifikan. LHR tertinggi dicapai pada sore hari yaitu sebesar $3032 \mathrm{SMP} / \mathrm{jam}$, sedangkan pada pagi hari mencapai 1439,5 SMP/jam dan siang hanya mencapai $981 \mathrm{SMP} / \mathrm{jam}$.

Tabel 1 Jumlah LHR Ruas 1 Menuju Semarang

\begin{tabular}{|c|c|c|c|c|c|c|c|c|}
\hline \multirow[b]{2}{*}{ Jam } & \multicolumn{6}{|c|}{ Ruas I } & \multirow{2}{*}{$\begin{array}{c}\text { LHR } \\
(\mathrm{SMP} / \mathrm{ja} \\
\mathrm{m})\end{array}$} & \multirow[b]{2}{*}{$\begin{array}{l}\text { LOS } \\
\text { (V/C) }\end{array}$} \\
\hline & $\begin{array}{l}\text { Mobil } \\
\text { (1) }\end{array}$ & $\begin{array}{c}\text { Mini Bus } \\
(1,5)\end{array}$ & $\begin{array}{c}\text { Bus / } \\
\text { Truk (2) }\end{array}$ & $\begin{array}{l}\text { Tronton } \\
\text { (2) }\end{array}$ & $\begin{array}{c}\text { Sepeda Motor } \\
(0,5)\end{array}$ & $\begin{array}{c}\text { Tidak } \\
\text { Bermotor }(0,5)\end{array}$ & & \\
\hline $\begin{array}{l}\text { Pagi (06.30 - } \\
07.30)\end{array}$ & 860 & 397,5 & 246 & 10 & 3132,5 & 2 & 4648 & 0,92 \\
\hline $\begin{array}{l}\text { Siang (11.30 - } \\
12.30)\end{array}$ & 395 & 91,5 & 524 & 460 & 2397,5 & 0 & 3868 & 0,77 \\
\hline $\begin{array}{l}\text { Sore }(16.00- \\
17.00)\end{array}$ & 1124 & 270 & 764 & 628 & 1355 & 4 & 4145 & 0,82 \\
\hline
\end{tabular}

Sumber : Survey dan Analisis, 2015 
Dari kedua nilai LHR untuk ruas jalan menuju Semarang dan ruas jalan menuju Kendal, dapat disimpulkan bahwa lalu lintas harian rata-rata di ruas jalan menuju Semarang lebih tinggi dibandingkan dengan volume lalu lintas harian rata-rata di ruas jalan menuju Kendal. Hal ini menunjukkan bahwa Kota Semarang menjadi salah satu pendorong bangkitan lalu lintas.

Tabel 2 Jumlah LHR Ruas II Menuju Kendal

\begin{tabular}{|c|c|c|c|c|c|c|c|c|}
\hline \multirow[b]{2}{*}{ Jam } & \multicolumn{6}{|c|}{ Ruas II } & \multirow{2}{*}{$\begin{array}{c}\text { LHR } \\
\begin{array}{c}\text { (SMP/ja } \\
\text { m) }\end{array} \\
\end{array}$} & \multirow[b]{2}{*}{$\begin{array}{l}\text { LOS } \\
\text { (V/C) }\end{array}$} \\
\hline & $\begin{array}{l}\text { Mobil } \\
\text { (1) }\end{array}$ & $\begin{array}{c}\text { Mini Bus } \\
(1,5)\end{array}$ & $\begin{array}{c}\text { Bus / } \\
\text { Truk (2) }\end{array}$ & $\begin{array}{l}\text { Tronton } \\
\text { (2) }\end{array}$ & $\begin{array}{c}\text { Sepeda Motor } \\
(0,5)\end{array}$ & $\begin{array}{c}\text { Tidak } \\
\text { Bermotor }(0,5)\end{array}$ & & \\
\hline $\begin{array}{l}\text { Pagi (06.30 - } \\
07.30)\end{array}$ & 256 & 57 & 396 & 444 & 286,5 & 0 & 1439,5 & 0,28 \\
\hline $\begin{array}{l}\text { Siang (11.30 - } \\
12.30)\end{array}$ & 192 & 73,5 & 216 & 118 & 380 & 1,5 & 981 & 0,19 \\
\hline $\begin{array}{l}\text { Sore }(16.00- \\
17.00)\end{array}$ & 162 & 70,5 & 432 & 432 & 1935 & 0,5 & 3032 & 0,60 \\
\hline
\end{tabular}

Survey dan Analisis, 2015

\section{b. Level Of Service (LOS)}

Berdasarkan hasil Studi Tatanan Transportasi Lokal Kota Semarang, kapasitas jalan di kedua ruas jalan di depan Terminal Mangkang adalah 5.053 - 6985 SMP/jam. Nilai kapasitas jalan yang akan digunakan untuk menghitung tingkat pelayanan jalan Semarang - Kendal diasumsikan menggunakan nilai kapasitas terendah yaitu 5053 $\mathrm{SMP} / \mathrm{jam}$.

Faktor pertumbuhan volume lalu lintas umumnya sebesar $8-10 \%$ per tahun, dalam hal ini diasumsikan faktor pertumbuhan volume lalu lintas paling tinggi yaitu sebesar 10\% per tahun dengan pertimbangan adanya Terminal Terpadu di Mangkang akan semakin menambah volume lalu lintas.

\section{c. Proyeksi Lalu Lintas Harian Rata-Rata (LHR)}

\section{Proyeksi LHR Kendaraan Di Ruas I Menuju Semarang}

Proyeksi LHR hingga 20 tahun ke depan pada ruas I arah menuju Semarang pada pagi hari mencapai $5671 \mathrm{SMP} / \mathrm{jam}$, siang hari mencapai $4720 \mathrm{SMP} / \mathrm{jam}$, dan sore hari mencapai $5058 \mathrm{SMP} /$ jam. Dengan kapasitas jalan mencapai $5058 \mathrm{SMP} / \mathrm{jam}$ maka tingkat pelayanan jalan akan mengalami kemacetan pada tahun 2034. Oleh sebab itu perlu adanya perencanaan untuk peningkatan kualitas jalan. Berikut ini dapat dilihat proyeksi LHR dan prediksi LOS untuk ruas jalan I.

\section{Proyeksi LHR Kendaraan Di Ruas II Menuju Kendal}

Proyeksi LHR hingga 20 tahun ke depan pada ruas II arah menuju Kendal pada pagi hari mencapai $1570 \mathrm{SMP} / \mathrm{jam}$, siang hari mencapai $1429 \mathrm{SMP} / \mathrm{jam}$, dan sore hari 
mencapai $5505 \mathrm{SMP} /$ jam. Dengan kapasitas jalan mencapai $5058 \mathrm{SMP} / \mathrm{jam}$ maka tingkat pelayanan jalan akan mengalami kemacetan pada tahun 2029. Oleh sebab itu perlu adanya perencanaan untuk peningkatan kualitas jalan.

Pergerakan kendaraan di ruas jalan ini lebih lancar karena jumlah LHR yang tidak begitu tinggi jika dibandingkan dengan LHR di ruas jalan menuju Semarang. Tetapi pada kondisi eksisting ruas II (sebelum titik survey ada kemacetan) akibat keberadaan bus yang menunggu penumpang tidak di terminal dengan mengambil bahu jalan di ruas II.

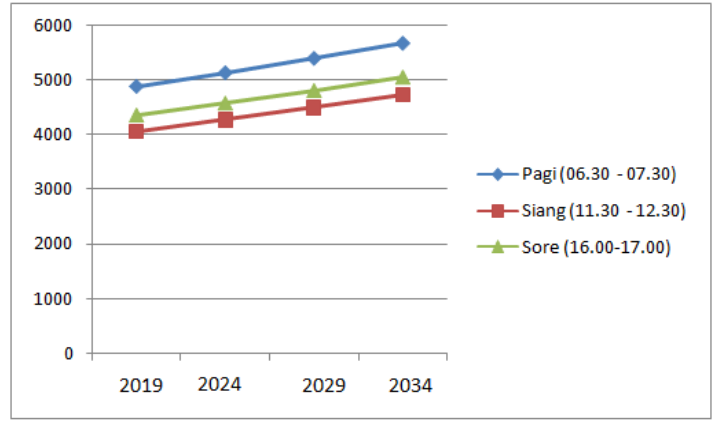

RUAS I

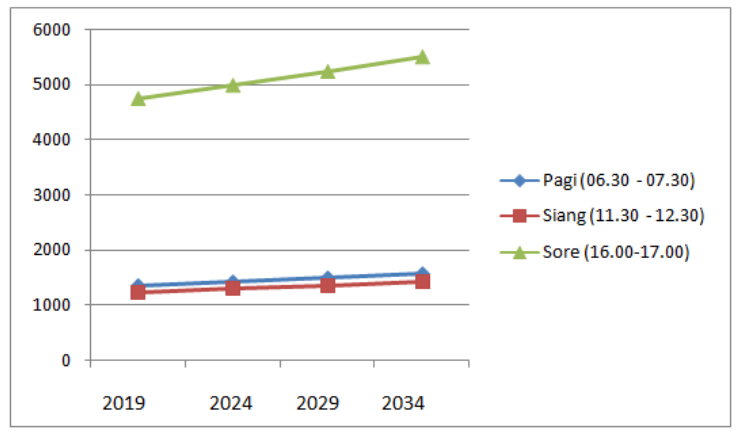

RUAS II

Gambar 3 Proyeksi LHR

Sumber : Hasil Analisis, 2015

Pada gambar diagram di atas menunjukkan bahwa semakin bertambah tahun semakin tinggi kebutuhan akan kapasitas jalan selaras dengan bertumbuhnya penduduk dan pelayanan yang mamadai sehingga sebelum 2024 perlu penambahan kapasitas jalan.

\section{d. Panjang Antrian Kendaraan}

Di kawasan Mangkang, aktifitas samping jalan sering menimbulkan konflik, dimana dampak yang di timbulkan berpengaruh terhadap arus lalu-lintas. Pengaruh hambatan samping ini yaitu angkutan umum dan kendaraan pribadi yang berhenti. Sering kali di temukan daerah bahu jalan dan trotoar, dijadikan daerah perparkiran, sehingga aktifitas ini dapat menimbulkan kemacetan. Kemacetan lalu lintas di ruas jalan tersebut akan menciptakan panjang antrian kendaraan. Panjang antrian yang terjadi pada suatu ruas jalan yang mengalami kemacetan lalu lintas berhubungan erat dengan waktu kemacetan yang terjadi. 
Kemacetan lalu-lintas yang ditimbulkan oleh aktifitas samping jalan, akan menurunkan arus kendaraan dan kecepatan kendaraan, yang melalui ruas jalan tersebut. Penurunan ini berdampak terhadap penurunan kapasitas ruang jalan tersebut.

Berdasarkan analisis yang dilakukan terhadap data survai di lokasi penelitian, diketahui bahwa panjang antrian rata-rata terpanjang adalah 26 meter.
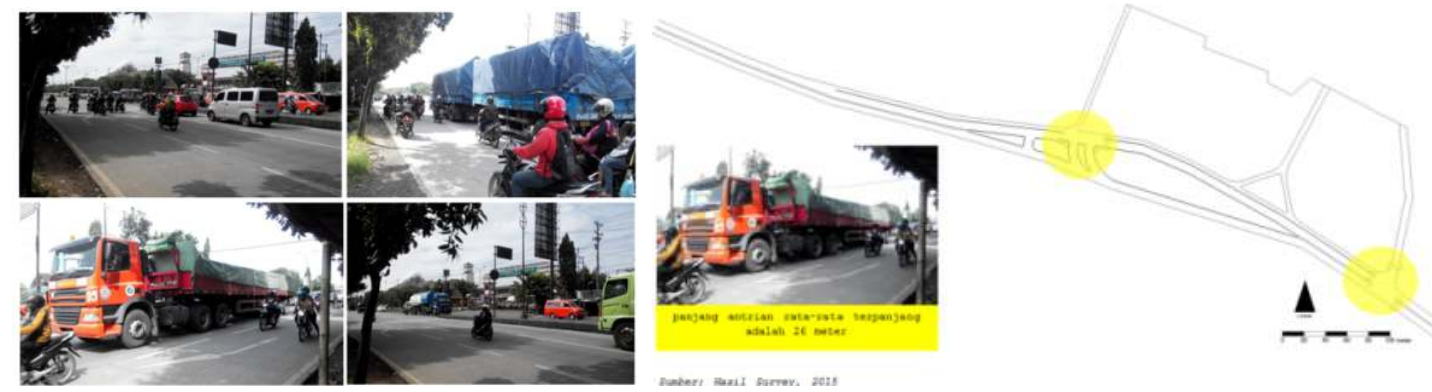

Gambar 4 Panjang Antrian Kendaraan

Sumber : Dokumentasi Pribadi, 2015

Tabel 3 Waktu Henti Traffic Light

\begin{tabular}{|c|c|c|c|}
\hline Titik traffic & MERAH & HIJAU & KUNING \\
\hline Titik 1 & 29 detik & 69 detik & 3 Detik \\
\hline Titik 2 & 23 detik & 30 detik & 3 Detik \\
\hline Titik 3 & 23 detik & 30 detik & 3 Detik \\
\hline Titik 4 & 29 detik & 69 detik & 3 Detik \\
\hline Titik 5 & 29 detik & 69 detik & 3 Detik \\
\hline Titik 6 & 29 detik & 10 detik & 3 Detik \\
\hline Titik 7 & 0 detik & 0 detik & 0 Detik \\
\hline Titik 8 & 29 detik & 69 detik & 3 Detik \\
\hline
\end{tabular}

Survey dan Analisis, 2015

Tabel 4 Panjang Antria Kendaraan

\begin{tabular}{|c|c|c|c|c|}
\hline \multirow{2}{*}{ Titik traffic } & \multicolumn{3}{|c|}{ Panjang Antrian } & \multirow{2}{*}{$\begin{array}{c}\text { Rata-rata panjang } \\
\text { antrian }\end{array}$} \\
\hline & $\begin{array}{c}\text { Pagi } \\
(06.30)\end{array}$ & $\begin{array}{l}\text { Siang } \\
(11.30)\end{array}$ & $\begin{array}{c}\text { Sore } \\
(16.00)\end{array}$ & \\
\hline Titik 1 & 28 meter & 12 meter & 38 meter & 26 meter \\
\hline Titik 2 & 4 meter & 4 meter & 8 meter & 5 meter \\
\hline Titik 3 & 5 meter & 8 meter & 5 meter & 6 meter \\
\hline Titik 4 & 0 meter & 0 meter & 0 meter & 0 meter \\
\hline Titik 5 & 20 meter & 12 meter & 26 meter & 19 meter \\
\hline Titik 6 & O meter & 0 meter & 0 meter & 0 meter \\
\hline Titik 7 & 0 meter & 0 meter & 0 meter & 0 meter \\
\hline Titik 8 & 19 meter & 14 meter & 34 meter & 22 meter \\
\hline
\end{tabular}

Survey dan Analisis, 2015 
Berdasarkan panjang antrian rata-rata terpanjang yang dapat terjadi di lokasi penelitian, sebaiknya terminal bayangan di depan terminal di tiadakan. Hal ini disarankan, agar tidak terjadi antrian kendaraan yang melewati panjang dari ruas jalan yang ada.

\section{Analisis Sarana Transportasi Terminal Mangkang}

Terminal Mangkang dengan luas 6,99 Ha berada di Kecamatan Tugu, Kota Semarang. Fasilitas yang ada di Terminal Mangkang cukup lengkap namun kondisinya tidak terawat (mangkrak). Fasilitas yang terdapat di Terminal Mangkang terdiri dari fasilitas utama dan penunjang.

- Fasilitas Utama seperti : Bangunan kantor terminal, menara pengawas, jalur kedatangan bus AKAP dan AKDP, jalur pemberangkatan bus AKAP dan AKDP, jalur pemberangkatan angkota dan angkudes, tempat parkir, tempat tunggu dan tempat istirahat kendaraan umum, ruang tunggu penumpang dan/ atau pengantar, loket penjualan karcis.

- Fasilitas Penunjang seperti : kamar kecil / toilet ,masjid, kios / warung, Ruang pengobatan, ruang menyusui, Ruang informasi dan pengaduan,ruang keamanan, ruang istirahat crew.

Beberapa permasalahan yang ada di Terminal Mangkang yaitu :

\section{a. Pangkalan bis (Angkota)}

Pangkalan Bis/ Angkota berada di dalam terminal yang digunakan untuk tempat pemberhentian angkutan kota untuk menunggu penumpang. Lokasi ini dapat dijangkau oleh pengunjung terminal. Namun kendala yang ada adalah banyaknya bis kota yang tidak masuk ke dalam terminal tetapi berada di luar terminal, hal tersebut mengakibatkan kemacetan di jalan raya depan terminal.

Penanganan yang perlu dilakukan adalah pemberlakuan dan pengawasan ketat supaya bis dan angkutan kota berhenti pada tempat yang sudah disediakan.

\section{b. Kios}

Di dalam Terminal Mangkang sudah tersedia kios-kios untuk berjualan, akan tetapi pemanfaatan kios tidak optimal (tidak digunakan) oleh sebab itu banyak bangunan yang rusak. Banyak pedagang memilih berjualan di area kedatangan dan keberangkatan penumpang.

Rencananya kios-kios ini akan dioptimalkan fungsinya sebagai tempat menjual berbagai kebutuhan penumpang, serta sebagai tempat untuk menjual oleh-oleh maupun souvenir khas Semarang. Perlu adanya pengaturan sirkulasi dalam terminal agar penumpang 
melewati kios-kios ini sehingga barang yang diperjualbelikan dapat laku terjual. Arahan yang dapat dilakukan untuk menyelesaikan permasalahan diatas yaitu:

- Penertiban pedagang dalam terminal agar berjualan pada tempat yang sudah disediakan.

- Pengaturan sirkulasi dalam terminal agar penumpang melalui kios-kios ini.

- Perbaikan bangunan kios.

- Pemberian tarif murah untuk sewa kios.

- Pemberian fasilitas lain seperti : ketersediaan air yang cukup, penerangan yang memadai.

\section{c. Hall}

Ruang yang disediakan untuk penumpang menunggu kedatangan bis berada di tengah dalam terminal Mangkang, namun jarang digunakan oleh pengunjung karena lokasinya yang jauh dengan tempat pemberhentian bus.

\section{d. Loket penjualan karcis}

Loket penjualan karcis sudah tersedia di dalam terminal Mangkang. Tersedia beberapa loket penjualan tiket dari masing-masing moda bus.

Namun banyak penumpang yang enggan untuk naik ke lantai dua dalam terminal. Penumpang memilih membeli tiket di dekat pemberhentian bus.

\section{e. Tempat peribadatan}

Tempat peribadatan disediakan di dalam terminal berupa ruangan mushola untuk di gunakan oleh pengunjung Terminal Mangkang, namun ruangan yang ada berkapasitas kecil sehingga apabila terminal berfungsi maksimal tidak dapat menampung pengguna terminal.

\section{f. Bangunan/Gedung}

Dari kondisi bangunan tersebut dimana peresmian pemanfaatan Terminal Mangkang yang belum lama dilaksanakan pada tanggal 1 Maret 2012 Terminal Mangkang, maka dengan kondisi yang seperti ini sangat mengkhawatirkan, memperlihatkan kalau bangunan terminal tidak terawat. Selain banyak lokasi yang tidak berfungsi, menjadikan Terminal Mangkang tidak terawat.

Perlu adanya penataan tata ruang terminal agar nyaman bagi pengunjung. Selain itu perawatan berkala harus tetap dilakukan agar kondisi terminal layak pakai. Dengan adanya perencanaan terminal yang terpadu dengan stasiun diharapkan dapat meningkatkan aktivitas yang ada di Terminal Mangkang. 


\section{g. Parkir}

Dalam terminal sudah disediakan tempat parkir namun masih ada beberapa kendaraan terutama jenis kendaraan sepeda motor yang parkir di sembarang tempat sehingga dapat mengganggu sirkulasi bus dan angkutan umum yang keluar masuk.

Perlu adanya penataan tata ruang dan sirkulasi parkir yang memudahkan aksesibilitas pengunjung terminal. Selain itu perlu adanya penindakan tegas terhadap kendaraan yang parkir di jalur sirkulasi kendaraan.

\section{h. Papan Informasi}

Terminal Mangkang sudah dilengkapi dengan papan informasi terutama berkaitan dengan lokasi ruangan. Namun papan informasi tersebut masih bersifat manual dan kurang menarik. Oleh sebab itu perlu adanya desain papan informasi maupun penunjuk arah yang menarik dan informatif sehingga memberikan kemudahan bagi pengunjung.

\section{i. Kondisi Angkutan Umum}

Kondisi angkutan umum yang masuk di area Terminal Mangkang, dari beberapa pengamatan ditemukan dengan kondisi rusak pada body minibus. Berdasar informasi yang didapat kondisi tersebut tidak diperhatikan para pengemudi bus. Alasan mereka adalah kondisi mesin masih bagus dan layak jalan untuk muatan penumpang.

Kelayakan kendaraan bermotor pada umumnya selain pada mesin kendaraan, kondisi body kendaraan juga harus diperhatikan. Karena salah satu cara menarik simpati penumpang adalah keadaan kendaraan yang bagus sehingga penumpang merasa nyaman dan aman.

Arahan:

- Pengecekan berkala kelayakan jalan pada angkutan umum.

- Pengadaan peremajaan kendaraan angkutan umum sesuai peraturan kelayakan jalan pada angkutan umum.

- Pengembangan jenis tranportasi kendaraan.

\section{j. Bus Rapid Transit (BRT)}

Tersedianya BRT di jalan pantura dapat membantu kelancaran lalu lintas. Karena pada dasarnya, tata cara pemberhentian pada saat keberangkatan dan penurunannya sudah tersedia tempat khusus yang disebut BRT (Bus Rapid Transit). Akan tetapi, perawatannya sangat kurang memadai, banyak halte BRT yang tidak terpakai untuk naik turunnya penumpang. Jalan yang dilalui BRT seharusnya mempunyai jalur sendiri, 
jadi tidak menjadi satu dengan kendaraan yang lainnya. Sehingga jalannya bisa lancar dan cepat.

BRT merupakan angkutan massal yang didesign lebih aman, nyaman dan diharapkan bisa lebih tepat waktu sampai tujuan. Harga tiket lebih terjangkau untuk masyarakat umum. Di kota besar dengan perkembangan kendaraan yang dimiliki masyarakat umum bisa memaksimalkan, sehingga dapat mengurangi kemacetan.

Arahan:

- Pembuatan jalur BRT sendiri supaya lebih aman, nyaman serta tepat waktu.

- Perbaikan halte-halte yang rusak.

- Penambahan jalur BRT ke segala tujuan.

\section{Analisis Tapak}

Dasar pertimbangan dalam pemilihan lokasi terminal adalah:

a. Terminal harus dapat menjamin kelancaran arus angkutan penumpang. Pada prinsipnya lokasi terminal terpadu harus dapat memenuhi syarat sebagai berikut :

- sebagai tempat pemindahan, pengaturan dan pengawasan naik turunnya penumpang.

- sebagai tempat bergantinya jenis angkutan dan moda transportasi.

b. Beberapa kriteria dalam pemilihan tapak untuk pembangunan terminal adalah:

- Memiliki aksebilitas (pencapaian) yang sangat baik. Bisa dijangkau dari segala arah, mudah.

- Memiliki lahan yang cukup luas, sehingga dapat menampung aktivitas didalamnya, diantaranya penyediaan lahan parkir yang memungkinkan penataan tapak, ruang luar, pedestrian, dan ruang terbuka dalam site.

- Terletak pada kawasan yang dapat memenuhi ataupun yang dapat mendukung kegiatan transportasi.

- Memiliki keterkaitan fungsi dengan fungsi lainnya yang berada disekitar tapak ini.

- Diupayakan merupakan lahan non produktif.

- Memiliki kontur yang relatif datar sehingga memudahkan alam pembangunan terminal terpadu.

Komponen analisis tapak terdiri dari:

\section{a. Analisis Lingkungan}

Adanya Terminal Mangkang yang berada dekat dengan kawasan permukiman menimbulkan sedikit gangguan terutama dalam hal kebisingan lalu lintas. Jika dibandingkan dengan kawasan industri di bagian timur, aktivitas terminal memiliki 
tingkat gangguan yang hampir sama dengan aktivitas industri. Kaitan lingkungan Terminal Mangkang dengan kebun binatang tidak begitu signifikan karena terpisah oleh jalan arteri primer.

\section{b. Anaisis Kebisingan}

Sirkulasi dalam site berpotensi sebagai penghasil kebisingan tertinggi di bandingkan jalan di depan site maupun kawasan di sekitarnya.

Kendala dari segi kebisingan:

Vegetasi yang ada disekeliling site saat ini dinilai belum mampu membuffer kebisingan yang ditimbulkan oleh sirkulasi kendaraan dari luar site.

- Sumber kebisingan dari Jl. Jendral Urip Sumoharjo, jaraknya sangat jauh dan bisa diabaikan.

- Sumber kebisingan terbesar dari jalur rel kereta api double track. Sifatnya temporer rutin. Beberapa pendekatan akustik antara lantai 1 dan lantai 2 bisa diterapkan.

- Sumber kebisingan internal seperti genset harus dapat diredam secara efektif.

Solusi yang diusulkan adalah:

a. Memberikan buffer berupa vegetasi dipinggir terluar tapak.

b. Peletakan area publik pada daerah yang mendapat tingkat kebisingan tertinggi.

\section{c. Analisis View}

Potensi pemandangan/view yaitu:

- Potensi view to site 1 potensial adalah dari luar terminal ke arah terminal. Penampilan bangunan harus menarik dari.

- Potensi view from site potensial adalah dari bangunan (terutama lantai 2) ke arah utara berupa bentangan sawah alami dan horizon pantai/laut

Kendala : perlu perhatian khusus untuk meletakan peralatan utilitas karena area tapak cukup terbuka.

Solusi :

1. Menempatkan buffer / masif pada bagian penempatan utilitas.

2. Bangunan diolah agar sesuai dengan tema.

\section{KESIMPULAN DAN SARAN}

Permasalahan Manajemen Transportasi di Kawasan Terminal Mangkang Kota Semarang, yaitu :

1. Akses Masuk dan Keluar Terminal 
a. Konflik lalu lintas yang terjadi di depan pintu masuk AKAP/ AKDP berupa konflik berpotongan (crossing) antara arus lalu lintas utama (arus menerus) dengan arus kendaraan dari arah timur yang masuk ke terminal.

b. Konflik lalu lintas yang terjadi di depan pintu keluar AKAP/ AKDP berupa konflik berpotongan (crossing) antara arus lalu lintas utama (arus menerus) dengan arus kendaraan yang keluar terminal menuju arah barat.

c. Selain itu juga terdapat konflik berupa konflik bersilangan (Weaving) antara arus kendaraan yang keluar dari terminal menuju barat dengan arus kendaraan yang masuk terminal dari arah timur.

2. Hambatan Lalu Lintas

a. Masih adanya kendaraan yang berhenti/ parkir untuk menaikkan/ menurunkan/ menunggu penumpang di luar terminal akan menimbulkan kerugian yaitu :

- Kapasitas ruas jalan akan berkurang sehingga lalu lintas akan terhambat.

- Penumpang akan menunggu angkutan di jalan sehingga akan mengurangi potensi pendapatan terminal serta rawan terhadap kecelakaan mengingat kecepatan lalu lintas cukup tinggi.

- Angkutan umum enggan masuk terminal sehingga potensi pendapatan terminal berkurang serta mengganggu pengaturan jam perjalanan angkutan.

b. Timbulnya angkutan umum yang menaikkan/ menurunkan penumpang di ujung tol krapyak akan mengurangi kapasitas persimpangan sehingga akan menimbulkan hambatan.

Permasalahan Tapak di Kawasan Terminal Mangkang, yaitu:

- Sistem kegiatan dan pemanfaatan lahan

Aktifitas yang terjadi di kawasan terminal Mangkang semakin meningat setelah adanya terminal Mangkang dan di dukung oleh keberadaan kawasan pariwisata. selain itu juga di rencanakan pembangunman stasiun yang terkoneksi dengan terminal.

- Penggunaan lahan

Penggunaan Lahan di kawasan terminal Mangkang beragam yang terdiri dari kawasan industri, pariwisata (kebun binatang Kota Semarang), Permukiman (Padat dan Sedang), persawahan

- Perkembangan wilayah

Dengan adanya terminal Mangkang aktivitas di sekitar kawasan terminal menjadi bertambah, sehingga berpotensi menimbulkan permasalahan dalam transportasi. 


\section{Saran}

1. Tata guna Terminal Mangkang akan dapat maksimal jika terminal bayangan disekitar terminal ditutup (dengan kebijakan)

2. Sarana dan prasarana serta pelayanan yang baik, guna menarik simpati penumpang.

3. Peremajaan kendaraan angkutan umum yang sudah tidak layak jalan.

4. Pemkot segera merealisasikan pembangunan konektivitas antara Terminal dan Stasiun Mangkang.

\section{DAFTAR PUSTAKA}

Fidel, Miro. (1997). Sistem Transportasi Kota, Bandung, Penerbit Tarsito.

Morlock, Edward.K. (1978). Introduction to transportation Engineering \& Planning. Mc. GrawHill Kogakuha.

Morlock, Edward.K. (1978). Pengantar Teknik dan Perencanaan Transportasi, Terjemahan. Jakarta; Penerbit Erlangga.

Tamin, Ofyar Z (1997) Perencanaan \& Pemodelan Transportasi, Bandung; Penerbit ITB.

Siahaan Daniel Adam's. Subowo Ari. Marom Aufarul. (2013). Implementasi Kebijakan Bus Rapid Transit (Brt) Trans Semarang di Kota Semarang. Jurnal Fakultas Ilmu Sosial dan Ilmu Politik.

Soebiyantoro. (2010). Pengaruh Ketersediaan Sarana Prasarana, Sarana Transportasi Terhadap Kepuasan Wisatawan. Jurnal Fakultas Ekonomi UPN, Surabaya.

Warpani Suwajoko. (1990). Merencanakan Sistem Pengangkutan, Bandung; Penerbit ITBF 